\title{
White grub (Coleoptera: Melolonthidae) mortality induced by Ophiocordyceps melolonthae
}

\section{Geraldo Salgado-Neto ${ }^{1 *}$ Marcos Braz Vaz $^{2}$ Jerson Vanderlei Carús Guedes ${ }^{1}$}

\author{
${ }^{1}$ Departamento de Defesa Fitossanitária, Universidade Federal de Santa Maria (UFSM), 97105-900, Santa Maria, RS, Brasil. E-mail: gsalgado@bol.com.br. \\ *Corresponding author. \\ ${ }^{2}$ Departamento de Estatística, Universidade Federal de Santa Maria (UFSM), Santa Maria, RS, Brasil.
}

ABSTRACT: The occurrence of white grub roots in soybean crops in the South of Brazil has gradually increased. However, there is not information on the biological control of grubs by entomopathogenic fungi. This study aimed to induce infection by Ophiocordyceps melolonthae and analyze longevity in Cyclocephala modesta and Dyscinetus gagates larvae (Coleoptera: Melolonthidae). In the laboratory, Cyclocephala modesta and Dyscinetus gagates had a mortality rate of $85 \%$ and $75 \%$, respectively.

Key words: biological control, dissemination, entomopathogen, entomopathogenic fungi, induced infection.

\author{
Mortalidade em corós (Coleoptera: Melolonthidae) \\ induzida por Ophiocordyceps melolonthae
}

RESUMO: A ocorrência de corós-praga de raizes em lavoura de soja, no Sul do Brasil, tem gradualmente aumentado. Entretanto, não há informação sobre controle biológico de corós por fungos entomopatogênicos. Este estudo tem o objetivo de induzir a infecção por Ophiocordyceps melolonthae e analisar a longevidade em larvas de Cyclocephala modesta e Dyscinetus gagates (Coleoptera: Melolonthidae). Em laboratório, Cyclocephala modesta e Dyscinetus gagates apresentaram uma taxa de mortalidade de 85\% e 75\%, respectivamente. Palavras-chave: controle biológico, disseminação, entomopatógeno, fungos entomopatogênicos, infecção induzida.

White grubs (Melolonthidae) with an annual or biannual life cycle occur in native grasslands and soybean crops in Brazil and their long larval stage coincides with the development of plants. Native species include Cyclocephala modesta Burm, 1855 and Dyscinetus gagates Burm, 1847 (Coleoptera: Melolonthidae) (CHERMAN et al., 2013 and 2014). In Brazil, natural epizootic diseases caused by the fungus Cordyceps sp. Fries, 1818 (Hypocreales: Cordycipitaceae), Beauveria bassiana (Balsamo) Vuillemin, 1912 (Hyphomycetes: Moniliaceae) and Metharhizium anisopliae (Metchnikoff) Sorokin, 1883 (Hypocreales: Clavicipitaceae) have been shown to cause the collapse of white grub population in wheat (GASSEN, 1992; SALVADORI, 2000; SALVADORI \& PEREIRA, 2006). Chemical control methods using inseticides have been the main control strategy to reduce the population densities of insects. However, the selection pressure induced by excessive applications may lead to the development of resistance in these populations. To minimize this problem, different biological control agents can be used, especially specific entomopatogenic microorganisms (DUARTE et al., 2016).

Ophiocordyceps is the largest genus of the family Ophiocordycipitaceae, originally described by PETCH (1931) for species of the Cordyceps, which have septate ascospores (PETCH, 1933; KOBAYASI, 1941; SUNG et al., 2007). Ophiocordyceps spp. infect different insect orders, mainly Blattaria, Dermaptera, Diptera, Hymenoptera, Hemiptera, Isoptera, Lepidoptera, Mantodea, Orthoptera, Odonata and Coleoptera (ARAÚJO \& HUGHES, 2014). Ophiocordyceps melolonthae (Louis René Tulasne and Charles Tulasne) G.H. Sung, J.M. Sung, Hywel-Jones and Spatafora, 2007 (Hypocreales: Ophiocordycipitaceae) is a strong entomopathogenic species infecting mainly white grub larvae (Melolonthidae) in Brazil (SALGADO-NETO et al., 2015).

As there is no record of infection induced by entomopathogenic fungi in white grubs (Melolonthidae) in Brazil, the objective of this study is to evaluate the capacity of $O$. melolonthae 
to induce mortality of $C$. modesta and D. gagates larvae, infected in the laboratory.

The study was developed under laboratory conditions $\left(26 \pm 2{ }^{\circ} \mathrm{C}\right.$ temperature, $50 \pm 10 \%$ relative humidity and $12 \mathrm{~h}$ photophase). Larvae of $C$. modesta and D. gagates were collected from soil trenches opened in soybean crops, in the district of Arroio Grande, municipality of Santa Maria, RS $\left(29^{\circ} 40^{\prime} \mathrm{S}\right.$ and $\left.53^{\circ} 44^{\prime} \mathrm{W}\right)$, in January/February 2014 (rainfall $75 \mathrm{~mm}$ and temperature of $25^{\circ} \mathrm{C}$, averages for the period). Samples were separated, quantified and identified in the laboratory, using taxonomic methods, as reported by COSTA (2006), PEREIRA \& SALVADORI (2006) and CHERMAN et al. (2013 and 2014).

The $2^{\text {nd }}$ and $3^{\text {rd }}$ instars of $C$. modesta $(40$ individuals) and $D$. gagates (40 individuals) larvae were separated and maintained individually in plastic recipients $(20 \times 30 \times 12 \mathrm{~cm})$, containing autoclaved soil and carrot pieces. Containers were inspected daily for rearing conditions $\left(26^{\circ} \mathrm{C}, 12 \mathrm{~h}\right.$ photoperiod and $50 \%$ relative humidity) and to replace the feed, as described by PARDO-LOCARNO (2002) and PARDO-LOCARNO et al. (2005).

Extract of $O$. melolonthae was obtained from infected larvae of Diloboderus abderus Sturm, 1826 (Coleoptera: Melolonthidae) collected in a native grassland, in the district of Umbú, municipality of Rosário do Sul, RS $\left(30^{\circ} 35^{\prime} \mathrm{S}\right.$ and $\left.54^{\circ} 46^{\prime} \mathrm{W}\right)$. Larvae were superficially disinfected and rinsed in sterile distilled water. Subsequently, the specimens with a whitish structure resembling a stroma of Ophiocordyceps were sent to the Instituto Biológico de São Paulo for molecular identification. The sequence obtained was deposited in GenBank, access code KR082313 (SALGADO-NETO et al., 2015). The stroma of $O$. melolonthae was kept in an incubation chamber $\left(25^{\circ} \mathrm{C}, 12 \mathrm{~h}\right.$ photophase and $50 \%$ relative humidity) and also frozen in the laboratory.

Five larvae of infected D. abderus showing stroma were triturated along with ten C. modesta healthy larvae ( $3^{\text {rd }}$ instars) in $250 \mathrm{ml}$ of sterile distilled water and the flask was placed in the incubation chamber $\left(25^{\circ} \mathrm{C}, 12 \mathrm{~h}\right.$ photoperiod and $50 \%$ relative humidity) for 7 days. After this period, the contents were stirred for 10 minutes. The resulting suspension was filtered and O. melolonthae spores were counted with the aid of a hemacytometer and optical microscope. The resulting suspension had its concentration adjusted to $10^{6}$ spores $\mathrm{mL}^{-1}$. Subsequently, $10 \mathrm{~mL}$ of the spore suspension in each container were inoculated with larvae and this suspension was sprayed on the surface of the soil and food, while the control treatment received only sterile distilled water.

Biological variables evaluated were the mortality rate and duration of the larval and pupal periods for both species as well as longevity in Melolonthidae larvae with induced infection from $O$. melolonthae in the laboratory. In the group without the $O$. melolonthae extract, the larval stage (second and third larval instars) of $C$. modesta lasted 99.9 days and the pupal stage lasted 10.0 days. In D. gagates, the larval period (second and third larval instars) lasted 53.9 days, and the pupal phase lasted 25.0 days.

In the group with the extract of $O$. melolonthae, the mortality rate of C. modesta and D. gagates larvae was $85 \%$ and $75 \%$, respectively (Figure 1), demonstrating the high rate of larval mortality (Figure 2). C. modesta (15\%)

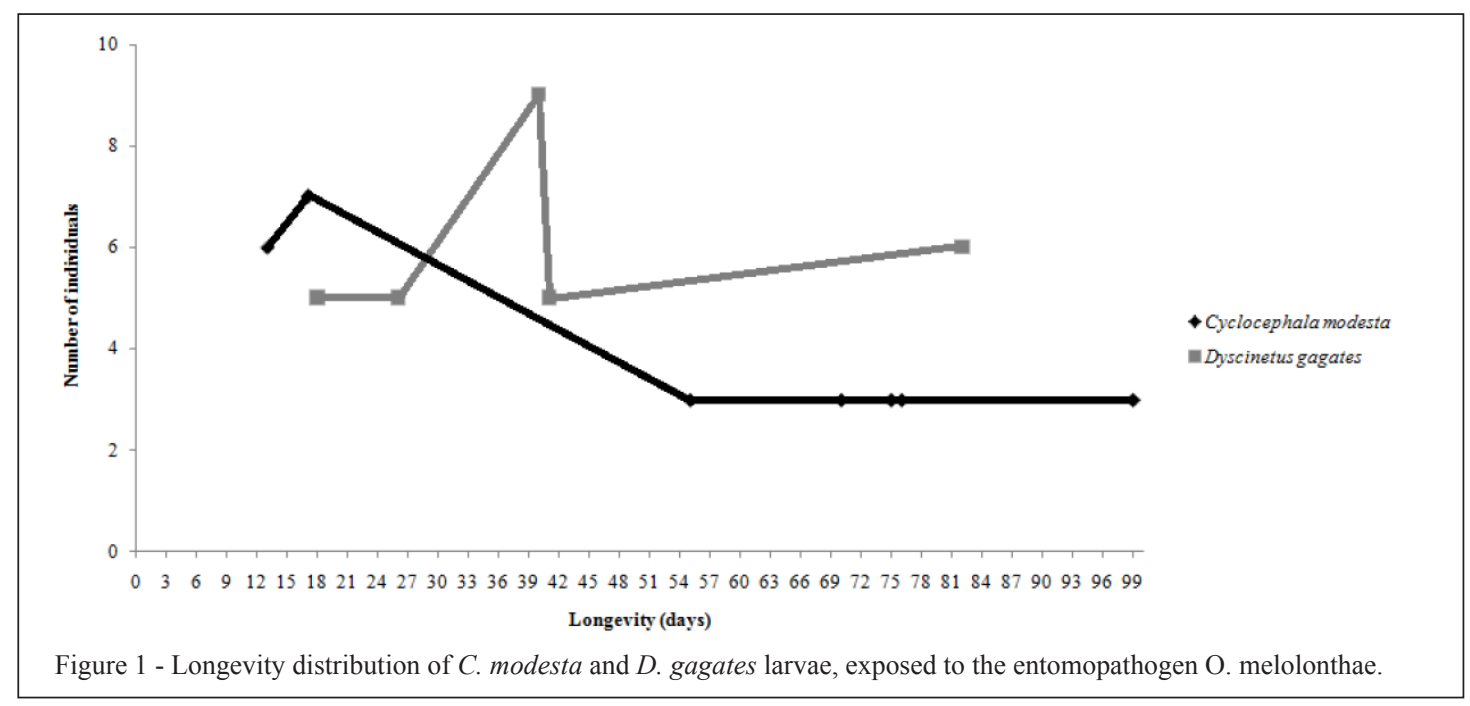

Ciência Rural, v.47, n.6, 2017. 


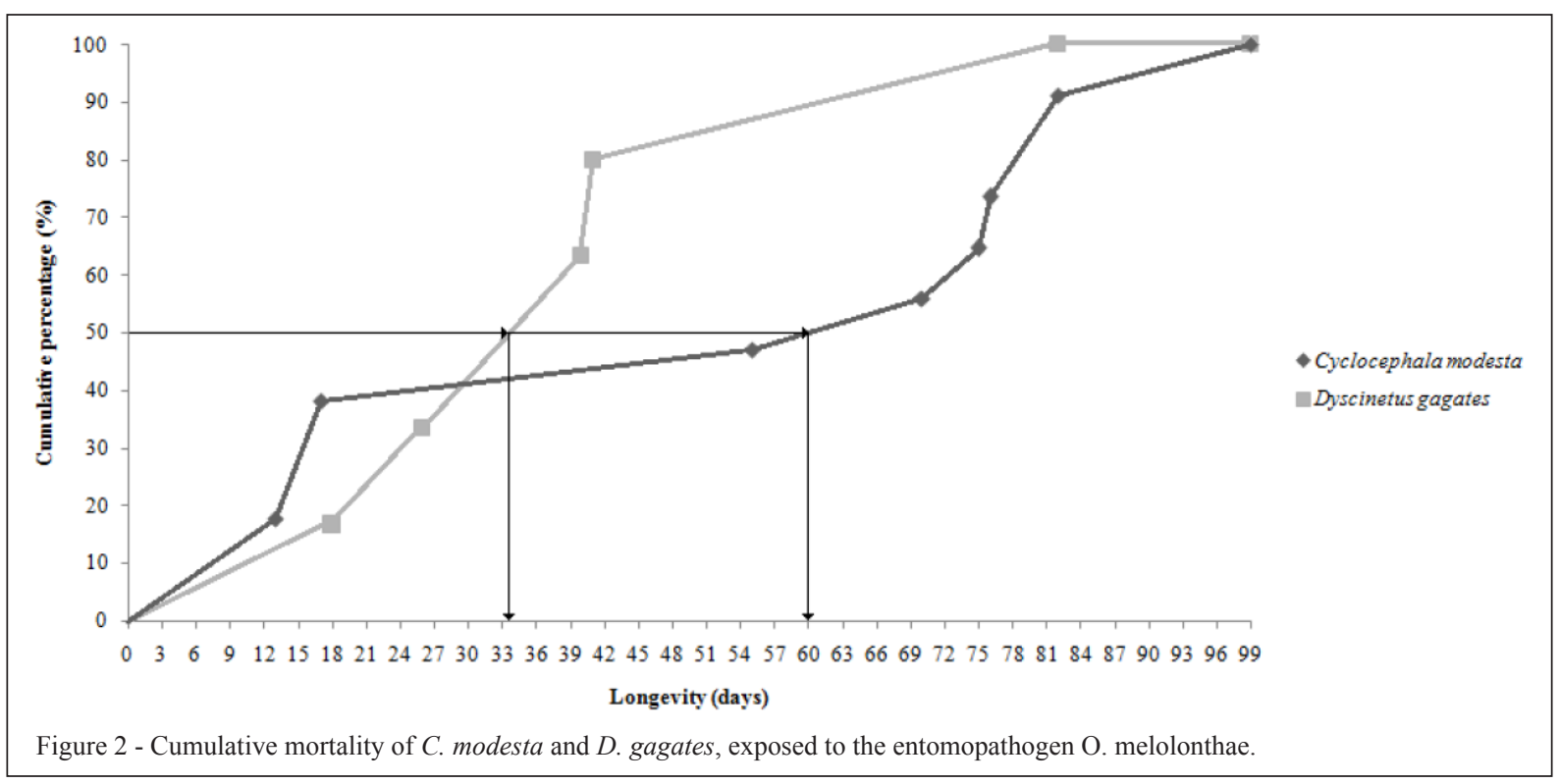

and $D$. gagates $(25 \%)$ larvae had a gross survival rate of only (20\%); however, they showed malformations (50\%) of survivors and death during the pupa-adult metamorphosis.

Distribution of white grubs in soybean crops occurred in aggregation, with the accumulation of specimens in infestation spots, as observed by LIEBHOLD et al. (1993). The period of larval activity of two species studied was similar to other Scarabaeidae collected in Brazil, as observed by RODRIGUES et al. (2010) and NOGUEIRA et al. (2013). Larval phase of Cyclocephala tucumana Brethes, 1904 and Cyclocephala melanocephala Fabricius, 1775 (Coleoptera: Melolonthidae) last 191.9 days and 70.7 days respectively (NOGUEIRA et al. (2013) and the larval phase of Cyclocephala verticalis Burmeister, 1847 (Coleoptera: Melolonthidae) last 195.7 days (RODRIGUES et al., 2010). White grubs (C. modesta and $D$. gagates) have a rhizophagous action that attacks soybean roots and inoculates Fusarium oxysporum Schlechtendahl emend. Snyder and Hansen, 1940 (Hypocreales: Tuberculariaceae) dispersing root rot in soy crops (SALGADO-NETO et al, 2016). The observed differences in the mortality rate are related to the differing periods of the life cycle between the two species. Knowing the duration of the larval stage in these species will help to induce their mortality.

The extract of $O$. melolonthae caused a gross rate mortality in white grubs of $80 \%$. This study confirmed the pathogenicity of $O$. melolonthae in larvae of $C$. modesta and $D$. gagates in the laboratory. The induced infection of white grubs by entomopathogenic fungi opens new possibilities for biological control. Duration of life cycle and behavior of white grubs are important for integrated management and precision agriculture.

\section{ACKNOWLEDGMENTS}

We thank Dr. Ricardo Harakava (Instituto Biológico de São Paulo), Laboratório de Bioquímica Fitopatológica, for his assistance in fungus identification and Ivair Valmorbida (Lab MIP/ UFSM) for his assistance in Melolonthidae larval identification, as well as Conselho Nacional de Desenvolvimento Científico e Tecnológico (CNPq) and Coordenação de Aperfeiçoamento de Pessoal de Nível Superior (CAPES) for financial support.

\section{REFERENCES}

ARAÚJO, J.P.M.; HUGHES, D.P. Diversity of entomopathogen fungi: which groups conquered the insect body? BioRxiv, 2014. Available from: <http://biorxiv.org/content/biorxiv/early/2014/04/04/003756. full.pdf>. Accessed: April. 07, 2017. doi: 10.1101/003756.

COSTA, C. Coleta, criação e identificação. In: COSTA, C. Insetos imaturos. Metamorfose e identificação. Ribeirão Preto: Holos, 2006. Cap.4, p.47-49.

CHERMAN, M.A. et al. White grubs (Coleoptera, Melolonthidae) in the "Planalto Region", Rio Grande do Sul state, Brazil: key for identification, species richnessand distribution. Revista Brasileira de Entomologia, v.57, n.3, p.271-278, 2013. Available from: <http:/www.scielo.br/ scielo.php?script=sci_arttext\&pid=S0085-56262013000300005>. Accessed: April. 07, 2017. doi: 10.1590/S0085-56262013000300005.

CHERMAN, M.A. et al. Ecological characterization of white grubs (Coleoptera: Melolonthidae) community in cultivated and noncultivated fields. Neotropical Entomology, v.43, n.3, p.282-288, 2014. Available 
from: <https://ink.springer.com/article/10.1007/s13744-014-0214-0>. Accessed: April. 07, 2017. doi: 10.1007/s13744-014-0214-0.

DUARTE, R.T. et al. Potential of entomopathogenic fungi as biological control agents of diamondback moth (Lepidoptera: Plutellidae) and compatibility with chemical insecticides. Journal of Economic Entomology, v.109, n.2, p.594-601, 2016. Available from: <https://academic.oup.com/jee/articleabstract/109/2/594/2379869/Potential-of-EntomopathogenicFungi-as-Biological>. Accessed: April. 07, 2017. doi: $10.1093 /$ jee/tow008.

GASSEN, D.N. Inimigos naturais de Diloboderus abderus, no sul do Brasil. In: REUNIÃO SOBRE PRAGAS SUBTERRÂNEAS DOS PAÍSES DO CONE SUL, 2., 1992, Sete Lagoas. Anais... Sete Lagoas: Embrapa-CNPMS, 1992. p.168.

KOBAYASI, Y. The genus Cordyceps and its allies. Science Reports of the Tokyo Bunrika Daigaku, sect. B, v.84, n.5, p.53-260, 1941.

LIEBHOLD, A.M. et al. Geoestatistics and geographic information systems in applied insect ecology. Annual Review of Entomology, v.38, p.302-327, 1993.

NOGUEIRA, G.A.L. et al. Aspectos biológicos de Cyclocephala tucumana Brethes, 1904 e Cyclocephala melanocephala (Fabricius, 1775) (Coleoptera: Scarabaeidae). Biota Neotropica, v.13, n.1, p.8690, 2013. Available from: <http://www.biotaneotropica.org.br/v13n1/ pt/abstract?article+bn01713012013>. Accessed: April. 07, 2017.

PARDO-LOCARNO, L.C. Aspectos sistemáticos y bioecológicos del complejo Chisa (Coleoptera: Melolonthidae) de Caldoso, Norte del Cauca, Colombia. 2002. 139f. Tesis (Maestría Biología) - Universidad del Valle, Facultad de Ciencias.

PARDO-LOCARNO, L.C. et al. Structure and composition of the white grub complex (Coleoptera: Scarabaeidae) in agroecological systems of northern cauca, Colômbia. Florida Entomologist, v.88, n. 4, p.355-363, 2005.
PEREIRA, P.R.V.S.; SALVADORI, J.R. Guia para identificação de corós rizófagos (Coleoptera: Scarabaeoidea: Melolonthidae) comumente encontrados em cereais de inverno, milho e soja no norte do Rio Grande do Sul. Passo Fundo: Embrapa Trigo, 2006. 12p. (Comunicado Técnico, 204).

PETCH, T. Notes on entomogenous fungi. Transactions of the British Mycological Society, v.16, p.55-75, 1931.

PETCH, T. Notes on entomogenous fungi. Transactions of the British Mycological Society, v.18, p.48-75, 1933.

RODRIGUES, S.R. et al. Aspectos biológicos de Cyclocephala verticalis Burmeister (Coleooptera: Scarabaeidae). Neotropical Entomology, v.39, n.1, p.15-18, 2010. Available from: <http://dx.doi. org/10.1590/S1519-566X2010000100003>. Accessed: April. 07, 2017.

SALGADO-NETO, G. et al. First report of the occurrence of Ophiocordyceps melolonthae (Ascomycota: Hypocreales: Ophiocordycipitaceae) in larvae of Diloboderus abderus Sturm (Coleoptera: Melolonthidae) in Brazil. Biota Neotropica, v.15, n.2, p.1-4, 2015. Available from: <http://dx.doi.org/10.1590/167606032015010814>. Accessed: April. 07, 2017.

SALGADO-NETO, G. et al. Fusarium oxysporum dispersion by larvae of Cyclocephala modesta, Dyscinetus gagates and Diloboderus abderus in Brazil. Ciência Rural, v.46, n.6, p. 943949. 2016. Available from: <http://dx.doi.org/10.1590/01038478cr20150471>. Accessed: April. 07, 2017.

SALVADORI, J.R. Coró-do-trigo. Passo Fundo: Embrapa Trigo, 2000. 56p. (Embrapa Trigo. Documentos, 17).

SALVADORI, J.R., PEREIRA, P.R.V.S. Manejo integrado de corós em trigo e culturas associadas. Passo Fundo: Embrapa Trigo, 2006. 12p. (Comunicado Técnico 203).

SUNG, G.H. et al. Phylogenetic classification of Cordyceps and the clavicipitaceous fungi. Studies in Mycology, v.57, n.1, p.5-59, 2007. 